\title{
Artisanal Shark Fishery at "Tres Marias" Islands and Isabel Island in the Central Mexican Pacific
}

Juan C. Pérez-Jiménez, Oscar Sosa-Nishizaki, and Emmanuel Furlong-Estrada

Centro de Investigación Científica y de Educación Superior de Ensenada (CICESE)

Km 107, Carretera Tijuana-Ensenada, B.C., Ensenada, México, C. P 22800

\section{David Corro-Espinosa}

Centro Regional de Investigación Pesquera (CRIP/INP)

Calzada Sabalo Cerritos S/N, Mazatlán, Sinaloa, México, Apdo. Postal 1177, C.P. 82010

\author{
Agustín Venegas-Herrera and Oscar V. Barragán-Cuencas \\ Centro Universitario de Ciencias Biológicas y Agropecuarias (CUCBA), Universidad de Guadalajara \\ Las Agujas, Nextipac, Zapopan, Jalisco, México, C. P. 45110
}

Pérez-Jiménez, J. C., O. Sosa-Nishizaki, E. Furlong-Estrada, D. Corro-Espinosa, A. Venegas-Herrera, and O. V. Barragan-Cuencas. 2005. Artisanal Shark Fishery at "Tres Marias" Islands and Isabel Island in the Central Mexican Pacific. J. Northw. Atl. Fish. Sci., 35: 333-343. doi:10.2960/J.v35.m489

\begin{abstract}
There is a lack of basic biological information on the shark species caught in the region around the "Tres Marias" Islands and Isabel Island in the Central Mexican Pacific. Intensive monitoring was undertaken from October 1995 to March 1996 of shark landings by the artisanal fleet at La Cruz de Huanacaxtle, Nayarit, that fished south of "Tres Marias" Islands and, from November 2000 to February 2001, of landings by another fleet that fished around Isabel Island and close to the "Tres Marias". Smooth hammerhead Sphyrna zygaena (35\%), silky shark Carcharhinus falciformis (27\%) and blue shark Prionace glauca (25\%) were the most important species of 2004 sharks observed at La Cruz de Huanacaxtle. At Isabel Island, the most important species of 7464 sharks sampled were $S$. lewini (49\%) and Pacific sharpnose shark Rhizoprionodon longurio (45\%). This paper describes the shark species caught at these islands, the catch per unit effort of the principal species throughout the fishing season, their length frequency distributions and percent mature, and gear selectivity issues.
\end{abstract}

Key words: artisanal fishery, CPUE, Central Mexican Pacific, length, maturity, sharks

\section{Introduction}

The types of vessels and gears used in Mexican shark fisheries vary regionally, as does the fishing season and the degree of utilization of the different species caught (Bonfil, 1994). Because of its long coast, the Pacific coast contributed $65 \%$ of the total shark catches of Mexico in the 1990 s, the remaining 35\% coming from the Gulf of Mexico and Caribbean (Anuario Estadistico de Pesca, SAGARPA, 2001).

In some regions of the Gulf of California, the shark fishery started in the early-1940s, when the price of shark liver oil increased. During these boom years, a number of fishermen with small boats became experts in shark fishing, acquiring its basic skills and technology (McGoodwin, 1976). Though activity diminished after the Second World War, there was a recovery in 1960s based on marketing products such as shark fins, hides, meat and fishmeal (Castillo-Géniz et al., 1996).
The shark fishery in Mexico grew from less than 5000 tons in the early-1960s to 25000 tons in the late-1970s, and was maximally exploited in the 1980s and 1990s (average 30000 tons each year) (Castillo-Géniz, 2001). This fishery has a significant social and economic value throughout the Gulf of California and the west coast of Baja California (Holts et al., 1998).

In the Central Mexican Pacific, off Nayarit State, shark fishing activities were normally carried out around Isabel Island and occasionally in the vicinity of "Tres Marias" Islands (McGoodwin, 1976) (Fig. 1). Studies on sharks found near "Tres Marias" Islands and around Isabel Island have investigated migratory patterns (Kato and Hernández-Carvallo, 1967), species composition (CorroEspinosa, 1996) and reproductive biology (Torres-Huerta, 1999) of the scalloped hammerhead Sphyrna lewini. In this paper we present information on catch-per-unit effort (CPUE) of the principal species, their length frequency 


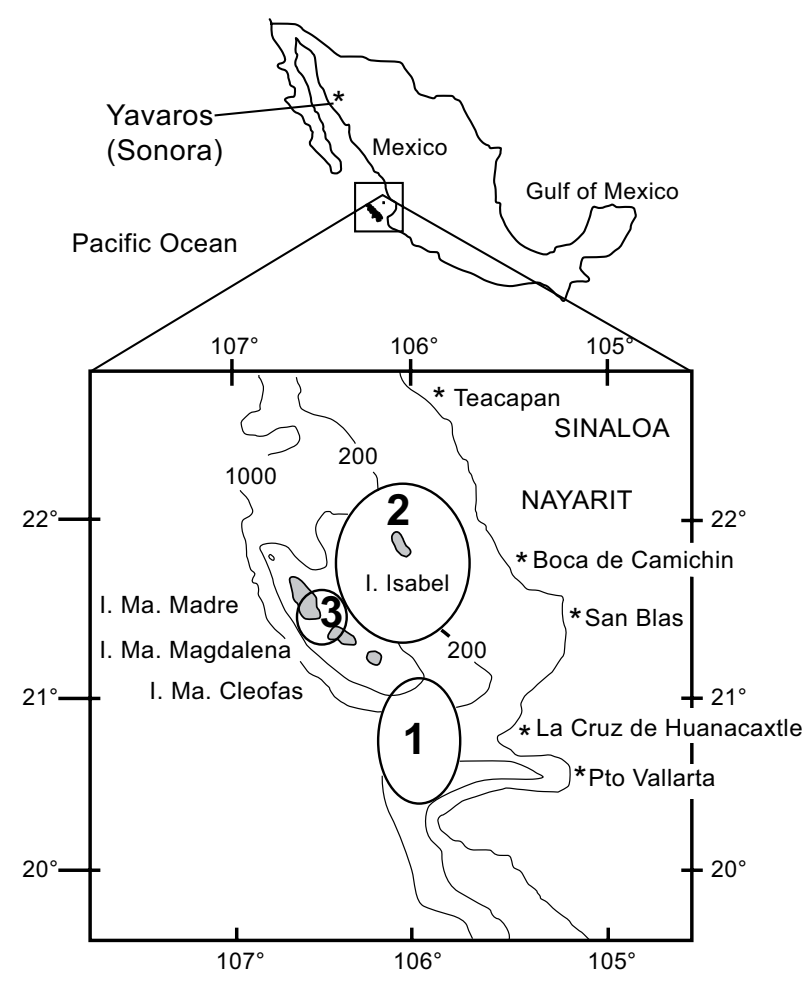

Fig. 1. Shark fishing areas in the Central Mexican Pacific: 1) south of the "Tres Marias" Islands, 2) around Isabel Island and, 3) close to the "Tres Marias" Islands. Isobaths are at 200 and $1000 \mathrm{~m}$.

distribution and percent mature, and gear selectivity issues.

\section{Material and Methods}

The Central Mexican Pacific can be considered a transitional region between tropical and temperate zones, where three water masses may be detected at the surface: 1) the cold, low salinity water of the California Current, present from January to April 2) the warm intermediate salinity water of the Tropical Oriental Pacific (by means of the Costa Rica Current, from August to December) and 3) the warm and highly saline water of the Gulf of California (Roden and Groves, 1959; Wyrtki, 1965; Stevenson, 1970; Badan, 1997). This allows both tropical and temperate species to be present in this region.

We obtained biological and fishery data each day from 26 October 1995 to 10 March 1996 (the whole shark fishing season) at La Cruz de Huanacaxtle, where 21 small boats that fished south of the "Tres Marias" Islands (area 1, Fig. 1) landed their catches and, from 15 November 2000 to 28 February 2001 (the fishing season lasted from the middle of October until April) at Isabel Island where between 10 and 60 small boats were fishing around the island (area 2, Fig. 1) and sometimes close to the "Tres Marias" (area 3, Fig. 1).

In both locations approximately 60 to $70 \%$ of all of the sets made by the fishers were sampled, recording the number of sharks per species, biological information and the fishing gear characteristics. Samples at La Cruz de Huanacaxtle were studied for the total length and sex and, for males, the internal face length of the claspers. At Isabel Island, the females' oviducal gland width, ovarian egg diameter and uterus width were measured.

Males were considered mature when claspers extended beyond the posterior edge of the pelvic fins, had a hardened internal structure and could be rotated toward the anterior part without bending (Holden and Raitt, 1975). Females landed at La Cruz de Huanacaxtle were considered mature when they had a total length larger than the smallest pregnant female recorded (Gubanov, 1978); though at Isabel Island we were able to use the presence of eggs about to be ovulated in the ovary and the width of the oviducal gland to evaluate maturity (Castro, 1989).

CPUE was estimated as the number of sharks per set caught by: a) two drift gillnets of $200 \mathrm{~m}$ length with $30 \mathrm{~cm}$ mesh size used south of "Tres Marias" Islands and, b) several fishing gears used around Isabel Island and close to "Tres Marias" Islands, using a standard number of hooks on longlines or the length of gillnets because these varied between fishermen (Table 1). Although seven different fishing gears were used at Isabel Island, we concentrated sampling effort on those used to target sharks. Sometimes fishermen used two different fishing gears on the same fishing trip (usually bottom-fixed gillnet with $8.5 \mathrm{~cm}$ mesh and bottom-fixed longline with $60 \mathrm{~mm}$ J hooks), and they often changed them depending on the availability of the various resources. The Kruskal Wallis test and the t-test and Mann Withney test (Zar, 1999) were used to test for statistical differences between the length of the sharks caught with the different fishing gears.

We obtained enough fishing effort and CPUE data to derive time series for drift gillnets used south of "Tres Marias" Islands and for bottom-fixed longline used around Isabel Island. The first time series was divided into "new moon" (from waning to crescent moon, representing dark nights) and "full moon" (from crescent to waning moon, representing light nights) periods. Because we noted periodicity in fishing effort and CPUE at Isabel Island, we divided the second time series into "new moon" and "full moon" periods and also into spring tides (days with 
TABLE 1. Fishing gears (arranged in order of importance) used around Isabel Island (fishing area 2), number of sets sampled, the targeted species and by-catch species.

\begin{tabular}{|c|c|c|}
\hline Fishing gears & Target species & By-catch species \\
\hline $\begin{array}{l}\text { 1. Bottom-fixed gill-nets } \\
8.5 \mathrm{~cm} \text { mesh size and } 600 \mathrm{~m} \mathrm{length}^{1} \\
63 \mathrm{sets}\end{array}$ & $\begin{array}{l}\text { - Several teleost species: mainly } \\
\text { Lutjanus peru and L. guttatus }\end{array}$ & $\begin{array}{l}\text { - Several teleost and ray species. } \\
\text { Small sharks (mainly juveniles of } \\
\text { Sphyrna lewini) }\end{array}$ \\
\hline $\begin{array}{l}\text { 2. Bottom-fixed longlines } \\
400 \mathrm{~J}_{\text {hooks }}^{1} 60 \mathrm{~mm} \text { length } \\
573 \text { sets }\end{array}$ & $\begin{array}{l}\text { - Small sharks "cazones" (several } \\
\text { species) and Lutjanus novemfasciatus }\end{array}$ & - Several rays and teleost species \\
\hline 3. Handlines & - Teleost species: genus Lutjanus & - Several teleost species \\
\hline 4. Harpoons & $\begin{array}{l}\text { - Several teleost species (mainly } \\
\text { L. novemfasciatus) }\end{array}$ & $\begin{array}{l}\text { - T. obesus and N. brevirostris were } \\
\text { caught with this fishing gear }\end{array}$ \\
\hline $\begin{array}{l}\text { 5. Drift gill-nets } \\
15 \text { and } 20 \mathrm{~cm} \mathrm{mesh} \mathrm{size} \mathrm{and} 1200 \mathrm{~m} \mathrm{length}^{1} \\
23 \text { sets }\end{array}$ & $\begin{array}{l}\text { - Small sharks "cazones" (several } \\
\text { species) }\end{array}$ & $\begin{array}{l}\text { - Rays of genus Mobula and several } \\
\text { teleost species }\end{array}$ \\
\hline $\begin{array}{l}\text { 6. Bottom-fixed longlines }{ }^{2} \\
120 \mathrm{~J}^{2} \text { hooks }^{1} 130 \mathrm{~mm} \text { length } \\
13 \text { sets }\end{array}$ & - Large sharks & - Small sharks: Mustelus lunulatus \\
\hline $\begin{array}{l}\text { 7. Drift longlines } \\
400 \mathrm{~J} \mathrm{hooks}^{1} \\
60 \mathrm{~mm} \text { length } \\
4 \text { sets }\end{array}$ & $\begin{array}{l}\text { - Small sharks "cazones" } \\
\text { (several species) }\end{array}$ & - Several teleost species \\
\hline
\end{tabular}

tidal amplitude $>104 \mathrm{~cm}$ ) and neap tides (days with tidal amplitude $<104 \mathrm{~cm}$ ) periods. Statistical differences were tested by means of t-test and Mann Withney U test (Zar, 1999) to determine if the periodicity in fishing effort and the CPUE were related with such phenomena. Tidal data for Puerto Vallarta, Jalisco (south of Nayarit State), which is the closest place with such records (www.cicese.mx, Physic Oceanographic Department from Centro de Investigacion Cientifica y de Educacion Superior de Ensenada, B.C., Mexico), showed the tides to be of semidiurnal type, strongly modulated on the lunar monthly spring/neap cycle.

\section{Results}

\section{The artisanal fleets}

The artisanal fleet operating out of La Cruz Huanacaxtle from the early-1990s to 1997 came from Chiapas (a southeastern State of Mexico) and exclusively targeted large sharks south of "Tres Marias" Islands between October and March, after which they moved to Yavaros in the Central Gulf of California (Fig. 1), following the migratory movements of some shark species (based on fishermen's comments). The by-catch of this fleet was estimated to be around $5 \%$ of the total catch and comprised, in order of importance: tunas of the genus Thunus, dolphin-fish Coryphaena hippurus, Pacific sailfish Istiophorus platypterus, blue marlin Makaira mazara and striped marlin Tetrapturus audax.

The artisanal fleet that landed at Isabel Island came from San Blas, Boca de Camichin and from Teacapan (Fig. 1) and has operated there since the 1940s. San Blas' fishermen mainly targeted teleost species (predominantly snappers) and fished for small sharks only when teleosts were not abundant. Boca de Camichin's fishermen mainly targeted small sharks and, sometimes, teleost species and large sharks. Fishermen from Teacapan only arrived at Isabel Island when the Pacific sharpnose shark Rhizoprionodon longurio appeared in catches, following this small shark species from north to south along the coast. At the end of the fishing season (in April), these fishermen returned to their towns because the price for fish products diminished after Easter ("Semana Santa") and because they had many problems operating at the beginning of the rainy season.

Except for a small group at San Blas, fishermen did not own the vessels and fishing gears, but were employees. Those of La Cruz de Huanacaxtle received 0.15 \$US per kg of whole shark caught, and those of San Blas and Boca de Camichin received gasoline, ice and money for provisions 
and, after staying from 5-10 days at Isabel Island, returned home and repaid their employer with fishing products, the surplus production being their reward.

\section{Shark species and length frequency distributions of the most important species}

We recorded 2004 sharks belonging to 10 species in 607 sets south of "Tres Marias" Islands; 7417 sharks belonging to 14 species in 663 sets around Isabel Island and, 47 sharks belonging to 9 species in 13 sets close to "Tres Marias" (Table 2). Most smooth hammerheads Sphyrna zygaena, silky sharks Carcharhinus falciformis and blue sharks Prionace glauca caught south of "Tres Marias" had lengths ranging from $165-205 \mathrm{~cm}$, and most S. lewini, R. longurio and C. falciformis caught around Isabel Island had lengths ranging from $75-105 \mathrm{~cm}$ (Fig. 2 ). The proportions of mature males and females of these species are also shown in Fig. 2.

\section{CPUE of the main species throughout the fishing season}

Two peaks of CPUE were observed during the fishing season south of "Tres Marias" (Fig. 3a): in November, when there were high catches of a tropical species the C. falciformis (Compagno, 1984) and, from January to March, when high catches of S. zygaena, a temperate and tropical species, and $P$. glauca, a predominantly temperate species (Compagno, 1984; Castro, 1996) were made. Most of the catch of S. lewini and C. limbatus and all $I$. oxyrinchus were caught in this second period. Thresher shark A. pelagicus was caught in small numbers in all months. This marked seasonality in catches for the main species may be related to the dynamic oceanographic conditions in the area.

South of "Tres Marias", the CPUE for C. falciformis using drift gillnets with $30 \mathrm{~cm}$ mesh size was higher during the new moon periods $(Z=-1.96, P<0.05)$ (Table 3$)$. There was no significant difference between the fishing effort carried out during both new moon (10.3 sets/day) and full moon ( 8.6 sets/day) periods $(t=1.12, \mathrm{df}=63$, $P=0.27)$.

Around Isabel Island, S. lewini was caught throughout the fishing season and $R$. longurio appeared in catches from the middle of January, and the CPUE time series of both species follow the same trend as the number of sets (Fig. 3b). Fishermen using bottom-fixed longline with 60 $\mathrm{mm} \mathrm{J}$ hooks at this island carried out significantly more sets during new moon (7.2 sets/day) than to full moon (4.7 sets/day) periods $(t=3.30, \mathrm{df}=74, P<0.01)$, but not at spring tides ( 7.8 sets/day) compared to neap tides (6.6 sets/day) $(t=0.98, \mathrm{df}=75, P=0.33)$. However, the highest CPUE for $R$. longurio was obtained during spring tides $(U=86.5, P<0.01)$ (Table 4$)$.

TABLE 2. Shark species caught south of "Tres Marias" Islands (Area 1, from October 1995 to March 1996), and around Isabel Island and close to "Tres Marias" Islands (Areas 2 and 3, from November 2000 to February 2001).

\begin{tabular}{|c|c|c|c|c|}
\hline Common names & Species & Area 1 & Area 2 & Area 3 \\
\hline Scalloped hammerhead & Sphyrna lewini & 88 & 3688 & 11 \\
\hline Pacific sharpnose shark & Rhizoprionodon longurio & 0 & 3375 & 0 \\
\hline Smooth hammerhead & Sphyrna zygaena & 700 & 182 & 1 \\
\hline Silky shark & Carcharhinus falciformis & 551 & 61 & 0 \\
\hline Blue shark & Prionace glauca & 503 & 2 & 0 \\
\hline Blacktip shark & Carcharhinus limbatus & 44 & 51 & 8 \\
\hline Pelagic thresher shark & Alopias pelagicus & 97 & 0 & 0 \\
\hline Whitenose shark & Nasolamia velox & 2 & 27 & 0 \\
\hline Tiger shark & Galeocerdo cuvieri & 1 & 17 & 6 \\
\hline Shortfin mako & Isurus oxyrinchus & 17 & 0 & 0 \\
\hline Dusky shark & Carcharhinus obscurus & 0 & 1 & 8 \\
\hline Sicklefin smoothhound & Mustelus lunulatus & 0 & 1 & 7 \\
\hline Bignose shark & Carcharhinus altimus & 0 & 6 & 0 \\
\hline Nurse shark & Ginglymostoma cirratum & 0 & 2 & 3 \\
\hline Smalltail shark & Carcharhinus porosus & 0 & 3 & 0 \\
\hline Whitetip reef shark & Triaenodon obesus & 0 & 0 & 2 \\
\hline Bull shark & Carcharhinus leucas & 0 & 0 & 1 \\
\hline Lemon shark & Negaprion brevirostris & 1 & 1 & 0 \\
\hline Total & & 2004 & 7417 & 47 \\
\hline
\end{tabular}



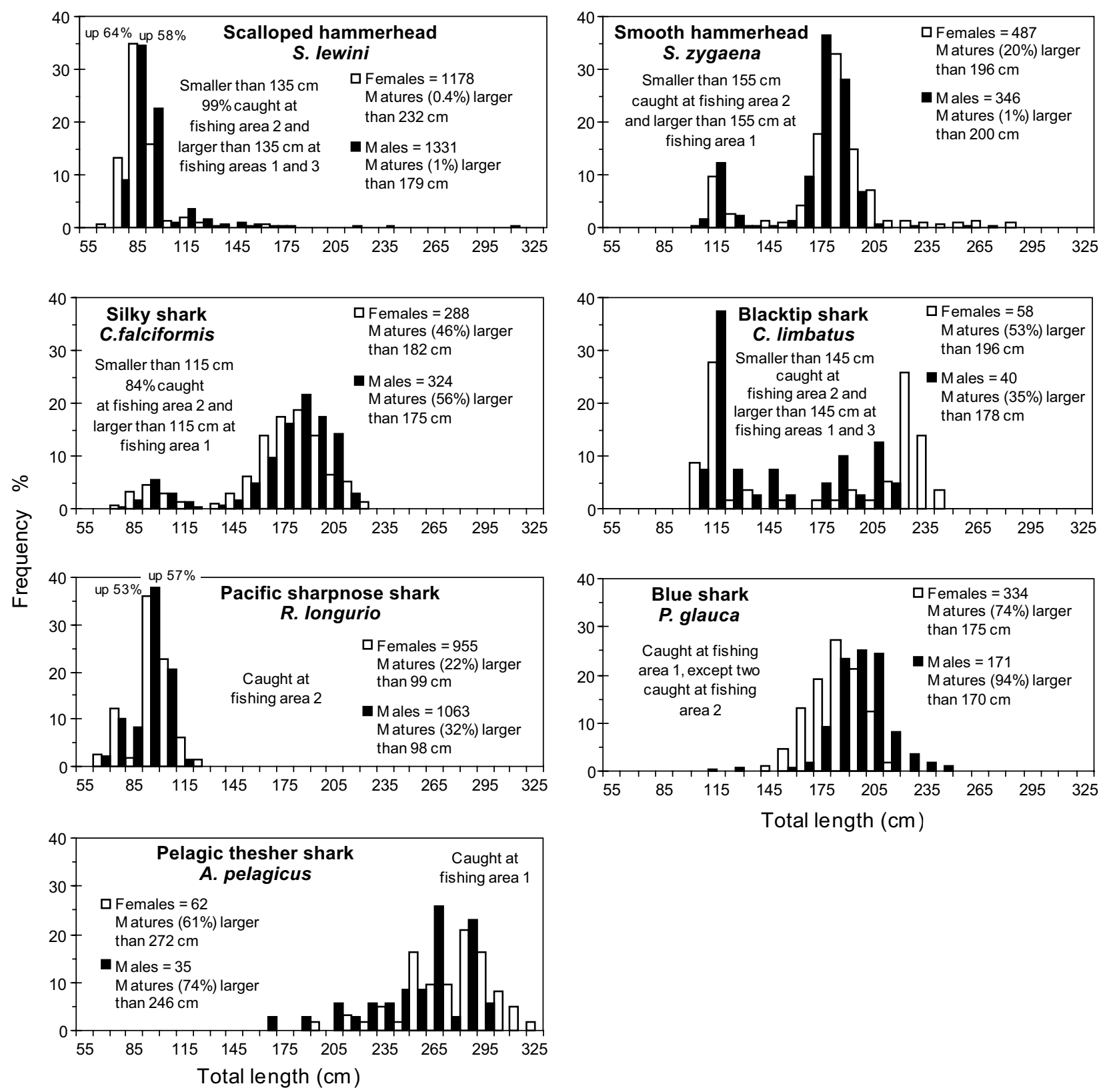

Fig. 2. Length-frequency distributions by the main shark species caught south of and close to "Tres Marias" Islands (fishing areas 1 and 3 ) and around Isabel Island (fishing area 2).

Although Fig. 4 shows that fishermen carried out sets during both spring and neap tide periods, the highest CPUE of $R$. longurio was obtained in days with tidal amplitudes $>110 \mathrm{~cm}$ (spring tides). S. lewini was caught throughout the tidal amplitude, but its highest CPUE tended to be on days with tidal amplitudes $<120 \mathrm{~cm}$.

\section{Fishing gear selectivity}

CPUE of the predominantly pelagic S. zygaena, C. falciformis and P. glauca was higher when fishermen used drift gillnets with 15-20 and $30 \mathrm{~cm}$ mesh, whereas CPUE of the demersal sharpnose shark was higher with bottom-fixed longline with $60 \mathrm{~mm} \mathrm{~J}$ hook, Table 5 . CPUE for S. lewini was higher in both drift gillnet with $15-20 \mathrm{~cm}$ mesh size and bottom longline with $60 \mathrm{~mm}$ $\mathrm{J}$ hooks, possibly because this species carries out vertical movements (Klimley et al., 1993).

The length distributions of the sharks caught with the different fishing gears varied considerably (Fig. 5), 

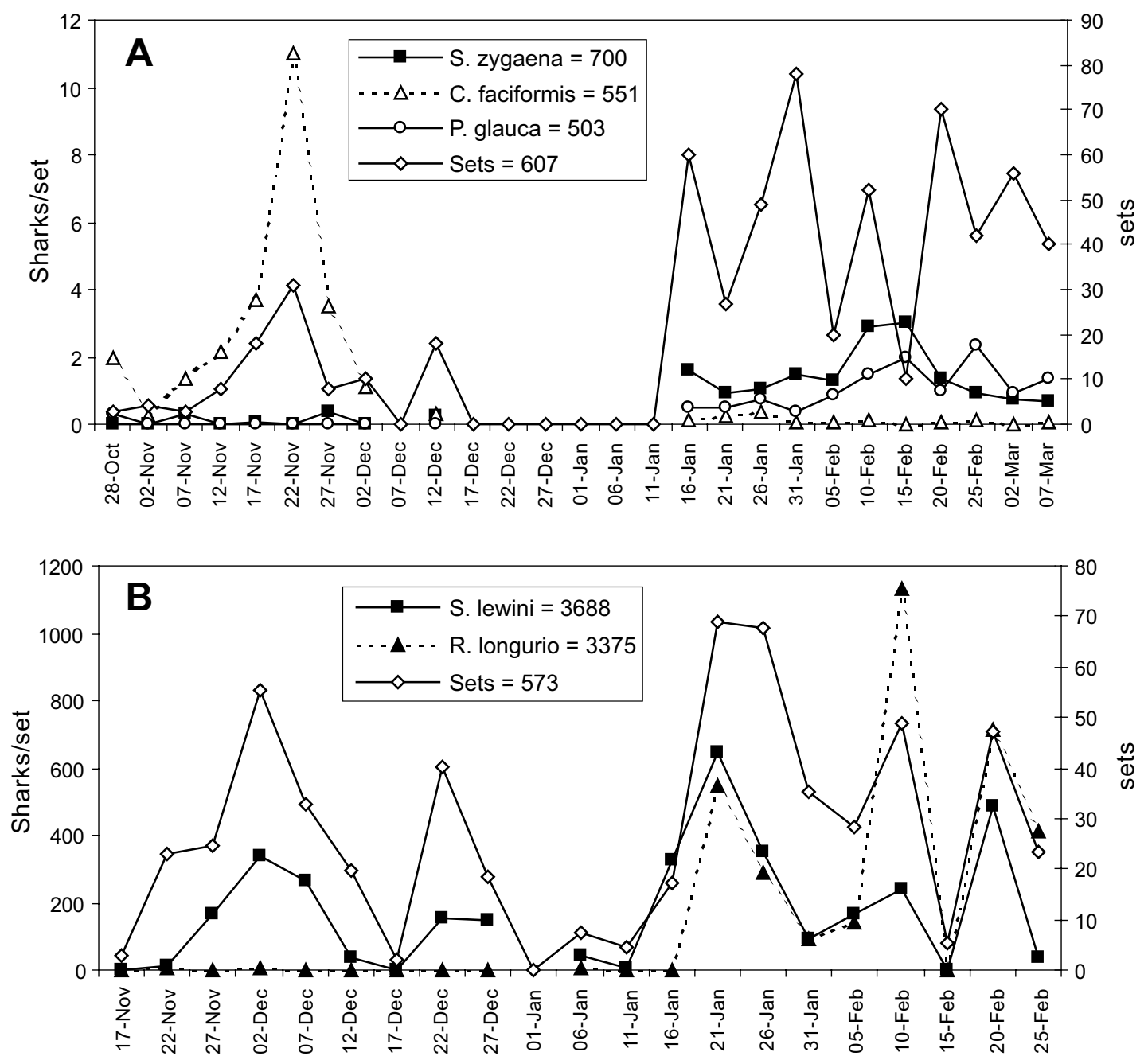

Fig. 3. Time series (each five days) of the main shark species caught: (A) south of "Tres Marias" Islands (fishing area 1) by drift gillnets with $30 \mathrm{~cm}$ mesh and, (B) around Isabel Island (fishing area 2) by bottom-fixed longline with $60 \mathrm{~mm} \mathrm{~J}$ hook. Note different scales in Figures a and $\mathrm{b}$.

as did their mean length (Table 6). However, in paired comparisons, we did not obtain significant differences between the length of the sharks caught: a) with bottom longline with $60 \mathrm{~mm} \mathrm{~J}$ hook and bottom-fixed gillnet with $8.5 \mathrm{~cm}$ mesh size $(t=-0.19$, df $=4601, P=0.84)$, or b) with bottom-fixed longline with $130 \mathrm{~mm} \mathrm{~J}$ hooks and drift gillnet with $30 \mathrm{~cm}$ mesh size $(Z=-0.30, P=0.76)$ (Table 7).

\section{Rays and skates}

Around Isabel Island, some ray species (whiptail stingray Dasyatis brevis, longtail stingray D. longus and speckled guitarfish Rhinobatos glaucostigma) were landed mainly when teleost and shark species were not abundant. Others ray species (Munk's devil Mobula munkiana, smoothtail mobula $M$. thurstoni and cownose ray Rhinoptera steindachneri) and a skate species (Haller's round ray Urobatis halleri) were discarded because of their low economic value.

\section{Discussion}

\section{Shark species composition in the catch}

In Mexico, catch statistics lack information on species composition, even for the most important shark species in the catch, and only catch trends can be assessed. Because effort information is also lacking, we have no information on trends in catch rate through time. All we can do is to identify the species considered as the most important in the catches in certain time and compare them with results from past studies. 
TABLE 3. Catch-per-unit effort of sharks caught south of "Tres Marias" Islands using drift gillnets with $30 \mathrm{~cm}$ mesh, compared between new and full moon periods.

\begin{tabular}{lccc}
\hline \hline Variables & New Moon & Full Moon & \multicolumn{1}{c}{ Statistics } \\
\hline S. zygaena/set & 1.1 & 1.2 & $t=-0.50, \mathrm{df}=63, P=0.61$ \\
C. falciformis/set & 1.6 & 0.2 & $Z=-1.96, P<0.05$ \\
P. glauca/set & 0.8 & 0.8 & $t=0.74, \mathrm{df}=63, P=0.46$
\end{tabular}
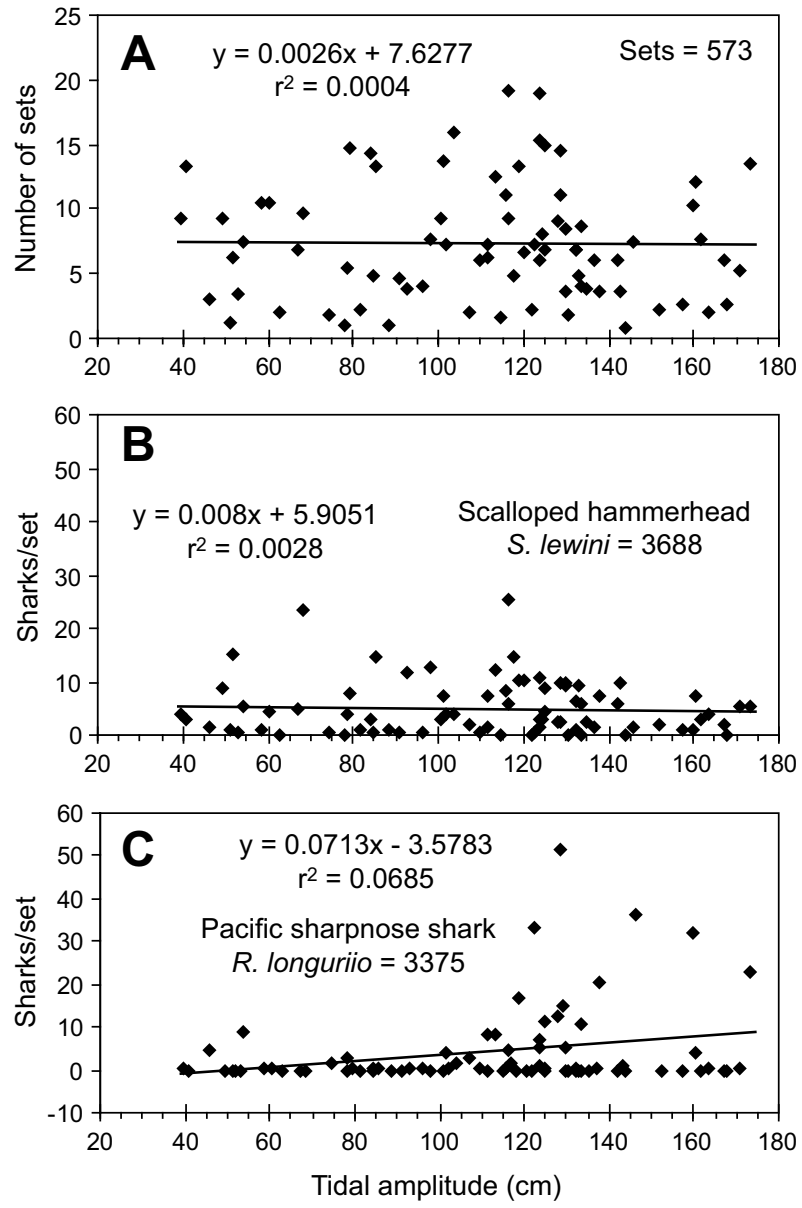

Fig. 4. Fishing effort (A) and catch per unit effort for S. lewini (B) and $R$. longurio $(\mathbf{C})$ in relation to tidal amplitude. Data including the sharks caught around Isabel Island (fishing area 2) by bottom-fixed longline with $60 \mathrm{~mm}$ J hook.

In this study we found that the shark fishery south and close to "Tres Marias" Islands and Isabel Island can catch up to 18 species of sharks. However, the catches were mainly of five species: S. lewini, R. longurio, S. zygaena, C. falciformis and P. glauca. Kato and Hernández-Carvallo (1967) noted that the principal species caught from Altata, Sinaloa to San Blas, Nayarit were C. limbatus, C. porosus,
$R$. longurio and S. lewini. During the late-1960s and through the 1970s and 1980s, R. longurio and juveniles of $S$. lewini were the most important small shark species caught on the southern coast of Sinaloa and sometimes close to Isabel Island, during autumn and winter months (the major production period) (Hernández-Carvallo, 1971; Saucedo-Barron, 1982; Rodríguez-García, 1986; CastilloGéniz, 1990). These authors reported that C. limbatus was frequently captured and the $C$. porosus was rarely captured, neither being considered important.

Based in these past reports and our information, we can assume that $R$. longurio and $S$. lewini have been exploited for three or four decades, though we have no evidence of overexploitation. During our study, fishermen pointed out that $R$. longurio shows up in large numbers only every two or three years, as in 2001. The artisanal fleet that was operating at La Cruz de Hunanacaxtle has not caught sharks south of "Tres Marias" Islands or in the Central Gulf of California since the late-1990s, reflecting, perhaps the decline in catch rates for all shark species in the Gulf of California as reported by Márquez-Farías (2000).

The biology of $R$. longurio is poorly known, but other species of the same genera (Atlantic sharpnose shark $R$. terranovae) are fast growing with early sexual maturity (Smith et al., 1998). R. longurio, therefore, may have a high capability of recovering from fishing pressure, which could explain why it is one of the most important shark species caught during the last three decades. However, $R$. longurio appears in catches of the central and southern part of the Gulf of California and the Nayarit coast only between November and May (Márquez-Farías, 2000), and its exploitation rate might not be as high as has been thought. It is not known where this species is distributed at other times, or if it is caught by other fisheries.

S. lewini has been described as a slow growing species, with late sexual maturity (Branstetter, 1987), hence with low recovery capability from fishing pressure (Smith et al., 1998). Using demographic analysis, Liu and Chen (1999) suggested that the $S$. lewini population in 
TABLE 4. Catch-per-unit effort for sharks caught around Isabel Island using bottom-fixed longline with $60 \mathrm{~mm}$ $\mathrm{J}$ hook, compared between new and full moon periods and between spring and neap tide periods.

\begin{tabular}{lccc}
\hline \hline Variables & New Moon & Full Moon & Statistics \\
\hline S. lewini/set & 6.6 & 5 & $Z=1.37, P=0.17$ \\
R. longurio/set & 4.9 & 8.2 & $t=-0.54, \mathrm{df}=74, P=0.59$ \\
& Spring Tides & Neap Tides & \\
S. lewini/set & 6.1 & 6.3 & $t=0.33, \mathrm{df}=75, P=0.74$ \\
R. longurio/set & 8.6 & 0.9 & $U=86.5, P<0.01$ \\
\hline
\end{tabular}

TABLE 5. Overall catch-per-unit effort of the principal shark species caught south and close to "Tres Marias" Islands and around Isabel Island by different fishing gear.

\begin{tabular}{lrrrrr}
\hline \hline Species & BLS & DGN30 & $\begin{array}{c}\text { Fishing gear } \\
\text { DGN15-20 }\end{array}$ & BGN8.5 & BLL \\
\hline S. lewini & 6.14 & 0.14 & 4.26 & 0.87 & 0.85 \\
R. longurio & 5.83 & 0 & 0.78 & 0.21 & 0 \\
S. zygaena & 0.15 & 1.15 & 4.0 & 0.01 & 0.08 \\
C. falciformis & 0.09 & 0.90 & 0.13 & 0 & 0 \\
P. glauca & 0 & 0.83 & 0.09 & 0 & 0 \\
C. limbatus & 0.08 & 0.07 & 0.04 & 0.03 & 0.61 \\
A. pelagicus & 0 & 0.16 & 0 & 0 & 0 \\
\hline
\end{tabular}

$\begin{array}{ll}\text { BLS } & =\text { Bottom-fixed longline with } 60 \mathrm{~mm} \mathrm{~J} \text { hooks } \\ \text { DGN30 } & =\text { Drift gillnet with } 30 \mathrm{~cm} \text { mesh size } \\ \text { DGN15-20 } & =\text { Drift gillnet with } 15-20 \mathrm{~cm} \text { mesh size } \\ \text { BGN8.5 } & =\text { Bottom-fixed gillnet with } 8.5 \mathrm{~cm} \text { mesh size } \\ \text { BLL } & =\text { Bottom-fixed longline with } 130 \mathrm{~mm} \text { J hooks }\end{array}$

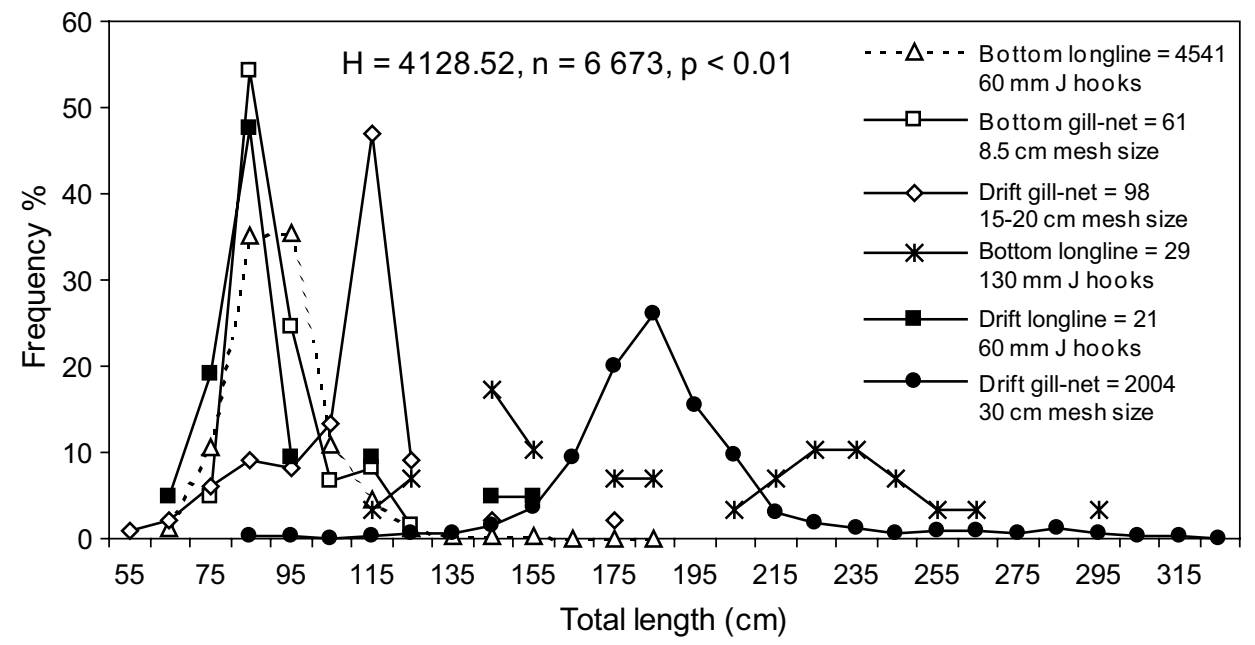

Fig. 5. Length-frequency distributions for all shark species combined, caught with different fishing gears south and close to "Tres Marias" Islands (fishing areas 1 and 3) and around Isabel Island (area 2). 
TABLE 6. Maximum, minimum and mean length of the sharks caught with the different fishing gear, and the number of boats that were using each gear by fishing area.

\begin{tabular}{|c|c|c|c|c|c|c|}
\hline & \multicolumn{6}{|c|}{ Fishing gear } \\
\hline & BLS & DGN30 & DGN15-20 & BGN8.5 & BLL & DLS \\
\hline Fishing Area $^{1}$ & Area 2 & Area1 & Area 2 & Area 2 & Area 3 & Area 2 \\
\hline Depth (m) & $15-80$ & surface & surface & $15-60$ & $15-90$ & surface \\
\hline Number of boats & 45 & 21 & 3 & 12 & 4 & 2 \\
\hline Shark caught & 4541 & 2004 & 98 & 61 & 29 & 21 \\
\hline Mean length $(\mathrm{cm})$ & 91 & 189 & 108 & 91 & 194 & 90 \\
\hline Min. length (cm) & 62 & 82 & 55 & 72 & 113 & 68 \\
\hline Max. length $(\mathrm{cm})$ & 188 & 325 & 175 & 124 & 298 & 150 \\
\hline
\end{tabular}

Fishing areas are presented in Fig. 1.

DLS = Drift longline with $60 \mathrm{~mm} \mathrm{~J}$ hooks, the other fishing gear symbology are presented at Table 5.

TABLE 7. Comparative matrix between the length of the sharks caught with the different fishing gears in the Central Mexican Pacific. (DLS = Drift longline with $60 \mathrm{~mm}$ J hooks, the other fishing gear symbology are presented at Table 5).

\begin{tabular}{|c|c|c|c|c|c|c|c|}
\hline & & & & Fis & gear & & \\
\hline & & BLS & DGN30 & DGN15-20 & BGN8.5 & BLL & DLS \\
\hline BLS & $Z$ & - & 63.15 & 9.79 & $-0.19^{1}$ & 9.26 & 2.29 \\
\hline & $\mathrm{df}$ & & - & - & 4601 & - & - \\
\hline & $P$ & & $<0.001$ & $<0.001$ & 0.84 & $<0.001$ & $<0.05$ \\
\hline DGN & & & & & & & \\
\hline & $Z$ & & - & -16.35 & -13.24 & -0.30 & $15.59^{1}$ \\
\hline & df & & & - & - & - & 1941 \\
\hline & $P$ & & & $<0.001$ & $<0.001$ & 0.76 & $<0.001$ \\
\hline DGN & & & & & & & \\
\hline & $Z$ & & & - & -6.13 & -7.74 & $3.79^{1}$ \\
\hline & df & & & & - & - & 117 \\
\hline & $P$ & & & & $<0.001$ & $<0.001$ & $<0.001$ \\
\hline $\mathrm{BGN}$ & & & & & & & \\
\hline & $Z$ & & & & - & -7.61 & 2.26 \\
\hline & $P$ & & & & - & $<0.001$ & $<0.05$ \\
\hline BLL & $Z$ & & & & & - & 5.74 \\
\hline & $P$ & & & & & & $<0.001$ \\
\hline
\end{tabular}

${ }^{1} t$-test.

the northwest Pacific would be resilient as long as fishing started after the age of first maturity, but would decline when fishing started on younger ages. Though our results and former studies in the area show that artisanal fisheries have been catching mainly juveniles for at least three decades, the data at hand do not indicate overexploitation of this species. Simpfendorfer (1999) suggested that, for some sharks species, sustainable exploitation may be possible if the youngest age-classes are targeted and older ages are left unfished. The fishery in the Central Mexican Pacific may have been using this strategy by coincidence, fishing in areas where mostly young ages are present and targeting sharks only when the more valuable shrimp and fin-fish species are not abundant. Nevertheless, in the southern part of the Gulf of California near La Paz, BCS, there are signs that the number of groups and individuals of older S. lewini, that congregate around a seamount on a yearly basis, are declining (P. Klimley, pers. comm.). 
Despite its socio-economic importance, the shark artisanal fishery in Mexico does not have well defined science-based management plan (Castillo-Geniz, et al. 1998), and both industrial and artisanal shark fisheries are managed only by a permit system. The intention to establish a legal management instrument designed to indicate specific measures for Mexican shark fisheries has been delayed since 2001 because of disagreement over the status of shark populations. However, as a precautionary approach, management measures as recommended by Castillo-Geniz et al. (1998) and Bonfil (1997) are needed.

\section{Shark sizes and availability}

The largest sharks were caught south and close to "Tres Marias" Islands, whilst numerous immature sharks were observed around Isabel Island, which could be explained by the presence of newborn and pregnant females in lagoons along the Sinaloa and Nayarit coasts (Corro-Espinosa, 1996; Torres-Huerta, 1999). Besides fishing gear selectivity, several shark species segregate by size (Springer, 1967), and this could have influenced differences in the lengths observed for S. lewini, S. zygaena, C. falciformis and C. limbatus.

Gillnet fishermen throughout the world have recognized that CPUE during the night is related to the lunar cycle, with the largest catches being usually made during the new moon (Hela and Laevastu, 1970). Whilst fishermen from Isabel Island using bottom-fixed longlines carried out more sets during new moon than during full moon periods, as might be expected, those from $\mathrm{La} \mathrm{Cruz}$ de Huanacaxtle using drift gillnets fished indiscriminately during both full moon and new moon periods. We suggest that future research should focus on the movements and migrations patterns of sharks in order to understand their seasonal presence in the area and their use of the water column, possibly using electronic tagging technologies (Boustany et al., 2002)

\section{Acknowledgements}

We thank Terrence I. Walker (Marine and Freshwater Resources Institute, Queenscliff, Australia), Vicente Ferreira Bartrina (Centro de Investigación Científica y de Educación Superior de Ensenada, Baja California, México) and J. Leonardo Castillo Géniz (Programa Tiburón del Instituto Nacional de la Pesca en México) for their valuable comments and suggestions, and Mónica González J. for support in field work in Isabel Island. The Parque Nacional Isla Isabel administration (SEMARNAT) provided valuable logistical support, and special thanks are due to the fishermen that made this work possible.

\section{References}

ANNUARIO ESTADISTICO DE PESCA. 2001. SAGARPA, $268 \mathrm{p}$.

BADAN, A. 1997. La corriente costera de Costa Rica en el Pacífico Mexicano. In: Contribuciones a la Oceanografía Física en México. M. F. Lavín (ed.). Monografía, 3: 99-112.

BONFIL, R. 1994. Overview of world elasmobranch fisheries. FAO Fish. Tech. Pap., 341: 119 p.

1997. Status of shark resources in the southern Gulf of Mexico and Caribbean: implications for management. Fish. Res., 29: 101-117.

BOUSTANY, A. M., S. F. DAVIS, P. PYLE, S. D. ANDERSON, B. J. Le BOEUF, and B. A. BLOCK. 2002. Satellite tagging, expanded niche for white sharks. Nature, 415: 35-36.

BRANSTETTER, S. 1987. Age, growth and reproductive biology of the silky shark Carcharhinus falciformis, and the scalloped hammerhead Sphyrna lewini, from the northwestern Gulf of Mexico. Environ. Biol. Fishes, 19: $161-173$.

CASTILLO-GENIZ, J. L. 1990. Contribución al conocimiento de la biología y pesquería del cazón bironche, Rhizoprionodon longurio, (Jordan y Gilbert, 1882) (Elasmobranchii, Carcharhinidae), del sur de Sinaloa, México. Tesis de Licenciatura, Universidad Nacional Autónoma de México, $128 \mathrm{p}$.

2001. Aspectos biológico-pesqueros de los tiburones que habitan las aguas del Golfo de México. Tesis de Maestría en Ciencias, Universidad Nacional Autónoma de México. 143 p.

CASTILLO-GENIZ, J. L., J. F. MARQUEZ-FARIAS, S. R. BONFIL, D. DE ANDA, R. MENA, R. VELEZ, and D. MENDIZABAL. 1996. La Pesquería de tiburón en México. In: Pesquerías relevantes de México, XXX Aniversario del INP, 1964-1992. Instituto Nacional de la Pesca/SEMARNAP, Tomes I and II: 365-415.

CASTILLO-GENIZ, J. L., J. F. MARQUEZ-FARIAS, M. C. RODRIGUEZ DE LA CRUZ, E. CORTES, and A. CID DEL RADO. 1998. The Mexican artisanal shark fishery in the Gulf of Mexico: towards a regulated fishery. Mar. Freshw. Res., 49: 611-620.

CASTRO, J. I. 1989. The biology of the golden hammerhead, Sphyrna tudes, off Trinidad. Environ. Biol. Fishes, 24(1): 3-11.

1996. The sharks of North American waters. $2^{\text {nd }}$ edition. Texas A \& M University Press, USA, 180 p.

COMPAGNO, L. J. V. 1984. Sharks of the world. An annotated and illustrated catalogue of sharks species known to date. FAO species catalogue, Vol. 4, Parts 1 and 2. FAO Fish Synop., 125: 655 p.

CORRO-ESPINOSA, D. 1996. Informe técnico anual (EneroDiciembre de 1995) del Programa Tiburón del CRIPMazatlán. 7 p.

GUBANOV, Y. P. 1978. The reproduction of some species of pelagic sharks from the equatorial zone of the Indian Ocean. J. Ichthyol., 18(5): 781-792.

HELA, I., and T. LAEVASTU. 1970. Fisheries oceanography. 
Fishing News (Books) LTD, London, 238 p.

HERNANDEZ-CARVALLO, A. 1971. Pesquería de los tiburones en México. Tesis Profesional en Biología, Escuela Nacional de Ciencias Biológicas IPN, México, 123 p.

HOLDEN, M. J., and D. F. S. RAITT. 1975. Manual de ciencia pesquera. Parte 2. Métodos para investigar los recursos y su aplicación. Documento Técnico de Pesca, FAO, 115, $211 \mathrm{p}$.

HOLTS, D. B., A. JULIAN, O. SOSA-NISHIZAKI, and N. W. BARTOO. 1998. Pelagic shark fisheries along the west coast of the United States and Baja California, México. Fish. Res., 39: 115-125.

KATO, S., and A. HERNANDEZ-CARVALLO. 1967. Shark tagging in the Eastern Pacific Ocean, 1962-1965. In: Sharks, Skates and Rays. P. W. Gilbert, R. F. Mathewson and D. P. Rall (eds). The John Hopkins Press, p. 93-109.

KLIMLEY, A. P., I. CABRERA-MANCHILLA, and J. L. CASTILLO-GENIZ. 1993. Horizontal and vertical movements of the scalloped hammerhead shark, Sphyrna lewini, in the southern Gulf of California, Mexico. Cienc. Mar., 19(1): 95-115.

LIU, K.M., and C.T. CHEN. 1999. Demographic analysis of the scalloped hammerhead, Sphyrna lewini, in the northwestern Pacific. Fish. Sci., 65(2): 218-223.

MARQUEZ-FARIAS, F. 2000. Tiburones del Golfo de California. In: SEMARNAP Sustentabilidad y Pesca Responsable en México: Evaluación y Manejo 1999-2000. INP, SEMARNAP, México, 237-257.

MCGOODWIN, J. R. 1976. Society, economy, and sharkfishing crews in rural Northwest México. Ethnology, 15: 377-391.

RODEN, G. Y., and G. W. GROVES. 1959. Recent oceanographic investigations in the Gulf of California. J. Mar. Res.,
18(1): $10-35$.

RODRIGUEZ-GARCIA, H. 1986. Contribución al estudio de la pesquería del tiburón en la zona sur del Estado de Sinaloa (Mazatlán). 'Memoria', Escuela de Ciencias del Mar, UAS, 94 p.

SAUCEDO-BARRON, C. J. 1982. El tiburón: contribución al estudio de la pesquería en la zona sur de Sinaloa, México. Ciencias del Mar, Universidad Autónoma de Sinaloa. Epoca 1, 1(4): 14-29.

SIMPFENDORFER, C. A. 1999. Demographic analysis of the dusky shark fishery in Southwestern Australia. Amer. Fish. Soc. Sym., 23: 149-160.

SMITH, S. E., D. AU, and C. SHOW. 1998. Intrinsic rebound potentials of 26 species of pacific sharks. Mar. Freshw. Res., 49: 663-678.

SPRINGER, S. 1967. Social organization of shark populations. In: Sharks, Skates and Rays. P. W. Gilbert, R. F. Mathewson and D. P. Rall (eds.). The John Hopkins Press, p. 149-174.

TORRES-HUERTA, A. M. 1999. Observaciones sobre la biología reproductiva de la cornuda barrosa Sphyrna lewini (Griffith and Smith, 1834) (Pisces: Sphyrnidae) en aguas del Noroeste de México. Tesis de Licenciatura, Escuela de Estudios Profesionales, Campus Iztacala, UNAM, 68 p.

STEVENSON, M. R. 1970. On the physical and biological oceanography near the entrance of the Gulf of California, October 1966-August 1967. Inter.-American Tropical Tuna Comisión, Bulletin XIV, 3: 482-503.

WYRTKI, K. 1965. Surface currents of the Eastern Tropical Pacific Ocean. Inter.-American Tropical Tuna Comisión, Bulletin IX, 5: 279-303.

ZAR, J. H. 1999. Bioestatistical analysis. Fourth edition, Prentice Hall, 663 p. 
